\title{
Factors Associated with Malocclusion in Preschool Children in a Brazilian Small Town
}

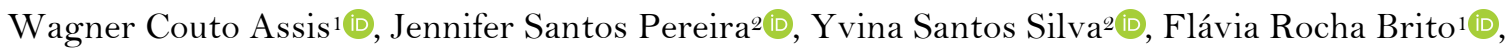 \\ Lorena Andrade Nunes ${ }^{1}\left[\right.$, Ícaro José Santos Ribeiro ${ }^{1}$, Cezar Augusto Casotti1 ${ }^{10}$
}

${ }^{1}$ Postgraduate Program in Nursing and Health, State University of South West of Bahia, Jequié, BA, Brazil.

${ }^{2}$ Department of Health, State University of South West of Bahia, Jequié, BA, Brazil.

Author to whom correspondence should be addressed: Wagner Couto Assis, Avenida Vavá lomanto, 15, Jequiezinho, Jequié, BA, Brazil. 45208-539. Phone: +55 73 3528-9648. E-mail: wagnerassis2010@hotmail.com.

Academic Editors: Alessandro Leite Cavalcanti and Wilton Wilney Nascimento Padilha

Received: 23 October 2019 / Accepted: 30 March 2020 / Published: 16 April 2020

How to cite this article: Assis WC, Pereira JS, Silva YS, Brito FR, Nunes LA, Ribeiro IJS, et al. Factors associated with malocclusion in preschool children in a Brazilian small town. Pesqui Bras Odontopediatria Clín Integr. 2020 ; 20 :e5351. https://doi.org/10.1590/pboci.2020.069

\begin{abstract}
Objective: To analyze the prevalence and factors associated with malocclusions in preschool children. Material and Methods: A census, epidemiological study, with a cross-sectional, descriptive and analytic sample, was carried out with children aged between 4 and 6 years, matriculated in preschools in the town of Aiquara, Bahia, Brazil. Malocclusion in the deciduous dentition was determined through the application of the index proposed by WHO, with the Foster and Hamilton criteria also being incorporated. The data was tabulated in duplicate in a Microsoft Excel spreadsheet and following correction, was analyzed using the SPSS, STATA and PAST Software. In order to identify the associated factors, we opted for Multiple Poisson regression analysis and Principal Component Analysis (PCA). Results: A total of 148 children were examined and the general prevalence of malocclusions was $69.59 \%$, with $57.5 \%$ in the group of 4-year-old, $76.92 \%$ those aged 5 years old and $72.46 \%$ among children aged 6 years old. In terms of primary canines, $66.2 \%$ were identified as class I, $25.7 \%$ as class II and $8.1 \%$ as class III. Normal overjet was $41.2 \%$, increased overjet $34.5 \%$, edge to edge bite $17.6 \%$ and anterior crossbite $6.8 \%$. The normal overbite $51.4 \%$, reduced $20.9 \%$ and deep $8.1 \%$. Of the individuals, $20.9 \%$ had posterior crossbite. In the Poisson regression analysis and PCA, a statistical association between the malocclusions and dental caries, duration of use of pacifiers, onychophagia and thumb sucking, was identified. Conclusion: The prevalence of malocclusion in preschool children in the small town of Aiquara is high and the associated factors identified are capable of control and prevention.
\end{abstract}

Keywords: Malocclusion; Child, Preschool; Public Health Dentistry; Epidemiology. 


\section{Introduction}

Malocclusions are changes in development and growth that affect the positioning of teeth [1], which cause changes from the aesthetic and functional point of view, with repercussions on chewing, swallowing, breathing and phonation [2].

In Brazil, this condition ranks third on the priority scale of oral health problems [3]. In the national territory when analyzing dental occlusion in children aged 5 years it was found that $20.3 \%, 75.3 \%, 85.4 \%$, 95.8\%, 3\% presented dental malocclusion with Class II occlusion in primary canine, increased overjet, augmented overbite, posterior crossbite, and anterior crossbite, respectively. In the Northeast region of Brazil, for the same parameters, the values found were $23 \%, 32.1 \%, 35.6 \%$ and $25.3 \%$, respectively [4].

Malocclusions have a multifactorial origin, with a series of influences including congenital, morphological, biomechanical and environmental problems [5]. The associated factors may have a primary origin (heredity and congenital changes) and a secondary aspect (deleterious habits, nutritional factors, changes in dietary pattern). They modify the position of the teeth and promote changes in the stomatognathic system [6]. The forces responsible for changing the positioning of the teeth can be physiological, emotional or learned, and the damage will be determined by the frequency, intensity, duration and type of object used, as well as, the child's age at the time of installation of the habits [7].

In childhood, especially in the formation and development of the orofacial complex, there is an association between malocclusions and oral habits (short period of breastfeeding, thumb or fingers sucking, tongue thrusting, use of pacifiers, habit of chewing pens and other objects) [7], family conflicts, school stress, irritations caused by teeth eruption, respiratory obstruction, poor posture [8]. We also highlight the learned muscle contraction patterns, of a complex nature, at first conscious and later unconscious, which can act as deforming factors of bone growth and development and dental positions [9]. The causes that promote the evolution of this process are very diverse, which means that malocclusion is also associated with socioeconomic and educational conditions [10].

A large part of Brazilian's health problems originates from social inequalities generated by the concentration of income, which causes enormous vulnerability for a large part of the population and numerous problems for smaller towns. Due to these factors, these little towns end up with not enough resources, which makes oral health care unequal and unfair, perpetuating the difficulty or even impossibility of access for a large part of the population [11].

Considering the high prevalence of this disease, the impacts caused on people's lives, and that many of the associated factors are suitable to prevention and control, this study aimed to analyze the prevalence and factors associated with malocclusion in preschool children aged 4 to 6 years residents of a small town with low bio-socio-demographic indicators.

\section{Material and Methods}

\section{Study Design and Sample}

This is a cross-sectional, using census data, analytical epidemiological study conducted with preschool children aged between 4 and 6 years matriculated in public elementary schools in the town of Aiquara, Bahia, Brazil. The town is located in the south-central region of the state of Bahia, had an estimated population of 4,725 inhabitants, in 2017, HDI (Human Development Index) of 0.552, Gini Index of 0.4661, poverty rate $54.74 \%$ [12] and $82 \%$ of families registered in the "Bolsa Família" social program [13]. 
A census study of preschool children, of both sexes, aged 4 to 6 years, who were enrolled and attending the preschool in the town, was carried out. Children whose parents did not authorize their participation in the study, children whose parents did not answer the questionnaire and children whose parents authorized the study, but at the time of the examination did not consent to it were excluded.

\section{Data Collection}

Initially, authorization was obtained from the chiefs of the Municipal Health and Education Secretariats to carry out the study. During this visit, information about all children enrolled in the school unit was requested (name, date of birth, home address and cellphone number of the children's parents). The parents/guardians answered a form with sociodemographic questions, eating and deleterious habits of the child.

Preschool children who met the study's inclusion criteria were invited to undergo to a clinical evaluation of the oral cavity. A trained dental surgeon performed a clinical examination of the oral cavity in an area in the preschool yard with adequate natural lighting. To perform the exam, a number 5 flat mouth mirror and a periodontal probe were used as proposed by the World Health Organization (WHO). During the exam, the researcher was accompanied by an assistant to record the data. To assess occlusion and dental caries in primary dentition, codes and criteria proposed by the World Health Organization and the Oral Health Project of the Brazilian Population were adopted [14].

To assess malocclusion in the primary dentition (dependent variable), the following diagnostic criteria were considered: Primary canine (Class I, Class II and Class III), overjet (normal, increased, edge to edge bite, anterior crossbite), overbite (normal, reduced, open bite, deep bite) and posterior crossbite (presence and absence). For data analysis, children with malocclusion were considered those with at least one of these variables: primary canine (class II and class III), overjet (increased, anterior crossbite or edge to edge bite), overbite (open or deep) and posterior crossbite (presence), absence of primary canine malocclusion (class I), overjet, overbite (normal) and absence of posterior crossbite [15].

The independent variables related to the parents were: sex (male and female), age (4, 5 and 6 years old), place of residence (urban and rural areas), skin color of the child (whites, non-whites - which includes blacks, light brown, Indian and yellow), marital status (single, married), education level ( $<8$ years, $>8$ years), if mother works (yes, no), if father works (yes, no), receives family allowance (yes, no), performed prenatal care (yes, no), dental prenatal care (yes, no) nutritional guidance (yes, no), type of birth delivery (natural, cesarean), prematurity in birth (yes, no), who takes care of the child (mother and father, others), who taught how to brush the teeth (mother and father, others). The independent variables related to malocclusion were: breastfeeding (yes, no), duration of breastfeeding ( $<6$ months, $>6$ months), baby bottle use (yes, no), duration of baby bottle use (up to one year, > 1 year), thumb or fingers sucking (yes, no), duration of thumb sucking (up to one year, > 1 year), onychophagia (yes, no), duration of onychophagia (up to one year, > 1 year), chewing objects (yes, no), experience of dental caries disease $(\mathrm{dmft}=0, \mathrm{dmft} \geq 1)$.

\section{Data Analysis}

The data were tabulated duplicated in a Microsoft Excel spreadsheet, and after corrections were transferred for analysis in the SPSS (Statistical Package for the Social Sciences) and STATA (Software for Statistics and Data Science) programs. Descriptive statistics were obtained using absolute and percentage values of categorical variables and measures of central tendency and dispersion of numerical variables. 
Thereafter, Person's chi-square test was applied to measure the association between malocclusion and the variables. The variables that in the chi-square showed a p-value $<0.20$ were selected for the multiple Poisson regression model with robust variance to measure the value of the association between malocclusions (expressed as "present" or "absent") and the covariates under investigation. In this study, in all analyzes, the level of statistical significance was $\mathrm{p}<0.05$.

In addition, it was decided to carry out the principal components analysis (PCA), biplot using the PAST program (Paleontological Statistics Software) [16]. The ACP identifies the relationship of the characteristics extracted from the data. The biplot method graphically represents the results of the PCA, so that this representation allows to visualize in a plane the relations and interrelationships between the lines and columns of the analyzed data, facilitating the identification of the associated factors of the studied diseases [17]. Thus, ACP analyzes a large number of original variables and condenses the information contained in a small set of variables, with the least possible loss of information. The biplot graphically represents the multidimensional data often associated with the ACP [18].

\section{Ethical Aspects}

The present study followed the ethical principles contained in Brazilian Resolution 466/12. The protocols were approved by the Human Research Ethics Committee of the State University of Southwest Bahia (Protocol No. 077/2018 CEP/UESB). All parents and/or guardians of preschool children were visited at home to obtain authorization for the child's participation in the study by signing the informed consent form.

\section{Results}

In the town of Aiquara, the prevalence of malocclusion was $69.59 \%$ and the associated factors were dental caries and dental prenatal care. The PCA identified an association between malocclusion and duration of use of pacifier, of onychophagia and of thumb or finger sucking.

At the time of the study (August 2018) there were 165 children aged 4, 5 and 6 years enrolled in the town's preschools. Twelve children out of this amount did not participate because the parents were not home after three visits and five of them did not consent the examination, even though the parents have authorized it. Thus, 148 children were examined, being $53.4 \%(n=73)$ composed by boys.

The children's average age was 5.19 years old ( \pm 0.83), in which 40 (27\%) aged 4 years, $39(26.4 \%)$ aged 5 and $69(46.6 \%)$ aged 6 years old. The greater number of children assessed at the age of 6 is because it is the age recommended by the Ministry of Education for entering school. Family income per capita was less than the minimum salary.

The prevalence of malocclusions in boys was $74.68 \%$ and in girls, $63.77 \%$. In children aged 4, 5 and 6 years old it was $57.5 \%, 76.92 \%$ and $72.46 \%$, respectively. In the analysis of occlusion, the following prevalence was identified: Primary canine: class I $(\mathrm{n}=98 ; 66.2 \%)$, class II $(\mathrm{n}=38,25.7 \%)$ and class III $(\mathrm{n}=12 ; 8.1 \%)$; Overjet: normal $(\mathrm{n}=61 ; 41.2 \%)$, increased $(\mathrm{n}=51 ; 34.5 \%)$ and edge to edge bite $(\mathrm{n}=26 ; 17.6 \%)$; anterior crossbite $(\mathrm{n}=10 ; 6.8 \%)$; Overbite: normal $(\mathrm{n}=76 ; 51.4 \%)$, reduced $(\mathrm{n}=31,20.9 \%)$ and deep $(\mathrm{n}=12 ; 8.1 \%)$; Posterior Crossbite: absence $(n=117 ; 79.1 \%)$ and presence $(n=31 ; 20.9 \%)$.

As seen in Table 1, the prevalence of malocclusions was higher in male preschool children, aged 6 years old, non-white, living in the urban area, whose parents/guardians are single, with low education level $(<$ 8 years). 
Table 1. Sociodemographic characterization of preschool children.

\begin{tabular}{|c|c|c|c|c|c|}
\hline \multirow{3}{*}{ Variables } & \multicolumn{4}{|c|}{ Malocclusion } & \multirow{3}{*}{ p-value } \\
\hline & \multicolumn{2}{|c|}{ Yes } & \multicolumn{2}{|c|}{ No } & \\
\hline & $\mathrm{N}$ & $\%$ & $\mathrm{~N}$ & $\%$ & \\
\hline \multicolumn{6}{|l|}{ Sex } \\
\hline Male & 59 & 57.3 & 20 & 44.4 & 0.150 \\
\hline Female & 44 & 42.7 & 25 & 55.6 & \\
\hline \multicolumn{6}{|l|}{ Age } \\
\hline 4 Years Old & 23 & 22.3 & 17 & 37.8 & 0.134 \\
\hline 5 Years Old & 30 & 29.1 & 9 & 20.0 & \\
\hline 6 Years Old & 50 & 48.5 & 19 & 42.2 & \\
\hline \multicolumn{6}{|l|}{ Residency Location } \\
\hline Urban Area & 60 & 58.3 & 31 & 68.9 & 0.221 \\
\hline Rural Area & 43 & 41.7 & 14 & 31.1 & \\
\hline \multicolumn{6}{|l|}{ Child's Skin Color } \\
\hline White & 19 & 18.4 & 11 & 24.4 & 0.404 \\
\hline Non-White & 84 & 81.6 & 34 & 75.6 & \\
\hline \multicolumn{6}{|l|}{ Parent's Marital Status } \\
\hline Single & 59 & 57.3 & 27 & 60 & 0.758 \\
\hline Maried & 44 & 42.7 & 18 & 40 & \\
\hline \multicolumn{6}{|l|}{ Mother's Education Level } \\
\hline$<8$ Years & 57 & 55.3 & 25 & 55.6 & 0.981 \\
\hline$>8$ Years & 46 & 44.7 & 20 & 44.4 & \\
\hline \multicolumn{6}{|l|}{ Father's Education Level } \\
\hline$<8$ Years & 74 & 71.8 & 33 & 73.3 & 0.852 \\
\hline$>8$ Years & 29 & 28.2 & 12 & 26.7 & \\
\hline \multicolumn{6}{|l|}{ Mother Works } \\
\hline Yes & 29 & 28.2 & 17 & 37.8 & 0.245 \\
\hline No & 74 & 71.8 & 28 & 62.2 & \\
\hline \multicolumn{6}{|l|}{ Father Works } \\
\hline Yes & 76 & 73.8 & 33 & 73.3 & 0.954 \\
\hline No & 27 & 26.2 & 12 & 26.7 & \\
\hline \multicolumn{6}{|l|}{ “Bolsa Família” Allowance } \\
\hline Yes & 87 & 84.5 & 32 & 71.1 & 0.060 \\
\hline No & 16 & 15.5 & 13 & 28.9 & \\
\hline \multicolumn{6}{|l|}{ Prenatal Care } \\
\hline Yes & 69 & 95.8 & 74 & 97.4 & 0.864 \\
\hline No & 3 & 4.2 & 2 & 2.6 & \\
\hline \multicolumn{6}{|l|}{ Dental Prenatal Care } \\
\hline Yes & 8 & 7.8 & 12 & 26.7 & 0.002 \\
\hline No & 95 & 92.2 & 33 & 73.3 & \\
\hline \multicolumn{6}{|l|}{ Nutrition Orientation } \\
\hline Yes & 51 & 49.5 & 28 & 62.2 & 0.154 \\
\hline No & 52 & 50.5 & 17 & 37.8 & \\
\hline \multicolumn{6}{|l|}{ Birth Delivery } \\
\hline Natural & 53 & 51.5 & 17 & 37.8 & 0.125 \\
\hline Cesarean & 50 & 48.5 & 28 & 62.2 & \\
\hline Prematurity & & & & & \\
\hline Yes & 4 & 3.9 & 5 & 11.1 & 0.091 \\
\hline No & 99 & 96.1 & 40 & 88.9 & \\
\hline People who Take Care o & & & & & \\
\hline Parents & 73 & 70.9 & 38 & 84.4 & 0.079 \\
\hline Others & 30 & 29.1 & 7 & 15.6 & \\
\hline Who Taught To Brush & & & & & \\
\hline Parents & 87 & 84.5 & 42 & 93.3 & 0.138 \\
\hline Others & 16 & 15.5 & 3 & 6.7 & \\
\hline
\end{tabular}


As described in Table 2, breastfed students prevailed, as well as those who used baby bottle, used pacifier, had the habit of thumb/finger sucking, onychophagia and had the habit of chewing objects.

Table 2. Breastfeeding and deleterious habits in preschool children.

\begin{tabular}{|c|c|c|c|c|c|}
\hline \multirow{3}{*}{ Variables } & \multicolumn{4}{|c|}{ Malocclusion } & \multirow{3}{*}{ p-value } \\
\hline & \multicolumn{2}{|c|}{ Yes } & \multicolumn{2}{|c|}{ No } & \\
\hline & $\mathrm{N}$ & $\%$ & $\mathrm{~N}$ & $\%$ & \\
\hline \multicolumn{6}{|l|}{ Breastfeeding } \\
\hline Yes & 99 & 96.1 & 44 & 97.8 & 0.607 \\
\hline No & 4 & 3.9 & 1 & 2.2 & \\
\hline \multicolumn{6}{|l|}{ Duration of Breastfeeding } \\
\hline$<6$ Months & 52 & 52.5 & 20 & 44.4 & 0.270 \\
\hline$>6$ Months & 47 & 47.5 & 25 & 55.6 & \\
\hline \multicolumn{6}{|l|}{ Use of Baby Bottle } \\
\hline Yes & 93 & 90.3 & 42 & 93.3 & 0.548 \\
\hline No & 10 & 9.7 & 3 & 6.7 & \\
\hline \multicolumn{6}{|l|}{ Duration of Baby Bottle } \\
\hline Up to 1 Year & 22 & 23.7 & 11 & 26.2 & 0.793 \\
\hline$<1$ Year & 71 & 76.3 & 31 & 73.8 & \\
\hline \multicolumn{6}{|l|}{ Use of Pacifiers } \\
\hline Yes & 74 & 71.8 & 36 & 80.0 & 0.296 \\
\hline No & 29 & 28.2 & 9 & 20.0 & \\
\hline \multicolumn{6}{|c|}{ Durations of Use of Pacifiers } \\
\hline Up to 1 Year & 27 & 36.5 & 17 & 47.2 & 0.316 \\
\hline$<1$ Year & 47 & 63.5 & 19 & 52.8 & \\
\hline \multicolumn{6}{|l|}{ Thumb/Finger Sucking } \\
\hline Yes & 63 & 61.2 & 30 & 66.7 & 0.524 \\
\hline No & 40 & 38.8 & 15 & 33.3 & \\
\hline \multicolumn{6}{|c|}{ Duration of Thumb/Finger Sucking } \\
\hline Up to 1 Year & 23 & 36.5 & 14 & 46.7 & 0.519 \\
\hline$<1$ Year & 40 & 63.5 & 16 & 53.3 & \\
\hline \multicolumn{6}{|l|}{ Onychophagia } \\
\hline Yes & 80 & 77.7 & 37 & 82.2 & 0.531 \\
\hline No & 23 & 22.3 & 8 & 17.8 & \\
\hline \multicolumn{6}{|l|}{ Duration of Onychophagia } \\
\hline Up to 1 Year & 25 & 31.3 & 12 & 32.4 & 0.815 \\
\hline$<1$ Year & 55 & 68.8 & 25 & 67.6 & \\
\hline \multicolumn{6}{|l|}{ Chew Objects } \\
\hline Yes & 59 & 57.3 & 25 & 55.6 & 0.845 \\
\hline No & 44 & 42.7 & 20 & 44.4 & \\
\hline \multicolumn{6}{|l|}{ Dental Caries } \\
\hline $\mathrm{dmft}=\mathrm{o}$ & 32 & 31.1 & 23 & 51.1 & 0.020 \\
\hline $\mathrm{dmft} \geq 1$ & 71 & 68.9 & 22 & 48.9 & \\
\hline
\end{tabular}

*dmft: decay, missing, filled teeth.

Table 3 shows the regression model after adjusted analysis. In the population analyzed, factors associated with malocclusion remained the variables of dental caries (risk factor) and prenatal dental performance (protective factor). 
Table 3. Multiple Poisson regression analysis between malocclusions and covariates under investigation.

\begin{tabular}{|c|c|c|c|c|}
\hline Variables & $\mathbf{N}$ & $\%$ & p-value & PR (IC95\%) \\
\hline \multicolumn{5}{|l|}{ Sex } \\
\hline Male & 79 & 53.4 & 0.220 & $1.23(0.72-1.07)$ \\
\hline Female & 69 & 46.6 & & \\
\hline \multicolumn{5}{|l|}{ Age } \\
\hline 4 Years Old & 40 & 27.0 & 0.159 & $141(0.96-1.23)$ \\
\hline 5 Years Old & 39 & 26.4 & & \\
\hline 6 Years Old & 69 & 46.6 & & \\
\hline \multicolumn{5}{|l|}{ Dental Prenatal } \\
\hline Yes & 20 & 13.5 & 0.018 & $2.36(0.30-0.89)$ \\
\hline No & 128 & 86.5 & & \\
\hline \multicolumn{5}{|l|}{ Nutrition Orientation } \\
\hline Yes & 79 & 53.4 & 0.504 & $0.67(0.74-1.15)$ \\
\hline No & 69 & 46.6 & & \\
\hline \multicolumn{5}{|l|}{ Birth Delivery } \\
\hline Natural & 70 & 47.3 & 0.083 & $1.73(0.69-1.02)$ \\
\hline Cesarean & 78 & 52.7 & & \\
\hline \multicolumn{5}{|l|}{ Prematurity } \\
\hline Yes & 9 & 6.1 & 0.164 & $1.39(0.35-1.19)$ \\
\hline No & 139 & 93.9 & & \\
\hline \multicolumn{5}{|c|}{ Who Take Care of the Child } \\
\hline Parents & 111 & 75.0 & O.191 & $1.31(0.91-1.55)$ \\
\hline Others & 37 & 25.0 & & \\
\hline \multicolumn{5}{|c|}{ Who Taught to Brush Teeth } \\
\hline Parents & 129 & 87.2 & 0.529 & $0.63(0.80-1.52)$ \\
\hline Others & 19 & 12.8 & & \\
\hline \multicolumn{5}{|l|}{$\mathrm{dmft}$} \\
\hline $\mathrm{dmft}=\mathrm{O}$ & 55 & 37.2 & 0.015 & $2.44(1.05-1.69)$ \\
\hline $\mathrm{dmft} \geq 1$ & 93 & 62.8 & & \\
\hline
\end{tabular}

PR: Poisson Regression; dmft: decay, missing, filled teeth.

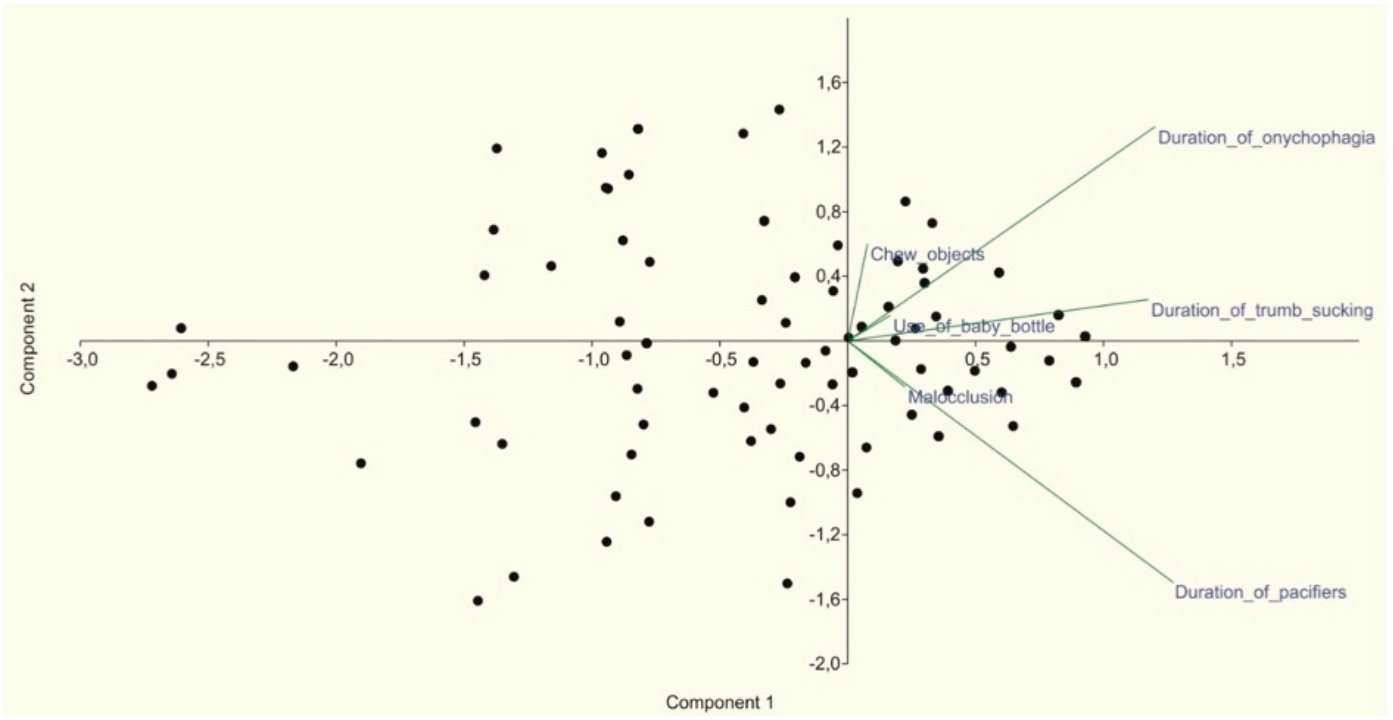

Figure 1. Scatter plot from principal component and biplot analyzes. Relationship between malocclusions and deleterious habits. 
In PCA, an association was identified between malocclusions and duration of use of pacifier, duration of onychophagia and duration of thumb/finger sucking. According to the Figure 1, it is noted that the first component - duration of use of the pacifier - is responsible for $28.2 \%$ of the variation, the second one duration of onychophagia - represents $16.8 \%$, and the third one - duration of thumb/finger sucking - only $7 \%$. Given these results, it is clear that preschool children who adopt deleterious habits for a longer period develop more malocclusions.

\section{Discussion}

Preschool children from Aiquara, aged 4 to 6 years old, have a high prevalence of malocclusions. The factors associated with malocclusions, in the multiple Poisson regression analysis were dental caries disease (risk factors) and the mother having access to dental prenatal care (protective factor). In PCA, the associated variables were the duration of use of pacifier, duration of onychophagia and duration of thumb/finger sucking.

In this study, the prevalence of malocclusion in children aged 4 to 6 years was $69.59 \%$, and in children aged 5 years, $76.92 \%$. These values corroborate with data obtained in Brazil and specific in the Northeast region, where the prevalence of malocclusion in children of five years of age was $66.7 \%$ and $64.8 \%$, respectively [4]. Higher values of the prevalence of malocclusions were obtained in Araraquara/SP, Brazil, where 87.4\% out of 135 children aged 3 to 6 years [10] presented malocclusion. Contrastingly, a study developed in Patos/PB, Brazil, 38.2\% from 131 preschool children aged 5 years showed some type of malocclusion [18], as well as in other studies carried out in the Northeast region that show a prevalence of $33.3 \%$ [19] and $34.5 \%$ $[20]$.

The most likely cause for the high prevalence of malocclusion in Aiquara may be associated with the presence of deleterious oral habits. It is known that these habits are strongly related to the presence of malocclusions, being configured as a potential factor in the development of changes in the structures and functions of the stomatognathic system [8].

Among the preschool children in Aiquara, one of the factors associated with malocclusion was dental caries $($ Poisson Regression $=2.4$ ). A multicenter study carried out with 4,776 Brazilian children aged 6 to 10 years living in Brazilian states identified an association between dental caries and/or tooth loss with malocclusions. In this study, the authors show a high prevalence of dental caries (52.9\%) causing $13 \%$ of premature tooth loss, and requiring orthodontic intervention, to maintain the space until the eruption of the permanent successor. It was also found that $23 \%$ of the children had a slight lack of space, due to the migration of adjacent teeth caused by tooth decay [3].

In Brazil, children have high rates of premature tooth extractions, without proper maintenance of space. Thus, extensive untreated caries lesions act as aggravating factors for malocclusion. When there is early loss of the deciduous tooth, a breakdown of dental balance occurs, which can cause mesialization, distalization and extrusion of other teeth. In addition, premature losses lead to a lack of space for permanent teeth, and consequently to malocclusions [21].

Dental caries was also a factor associated with malocclusion in 985 children aged 5 and 12 years old in São Paulo/SP, Brazil. The prevalence of severe malocclusions was higher (Poisson Regression $=1.5$ ) in the population with caries disease [21]. Another study carried out in Recife/PE, Brazil, with 105 children aged 4 to 6 years, identified an association between the prevalence of dental caries and the presence of posterior crossbite and mandibular overjet in mixed dentition [22]. In addition to often causing premature extraction of 
deciduous teeth, dental caries also lead to the development of irreversible dento-skeletal changes that affect facial aesthetics, causing damage to chewing and speech [3].

Among the preschool children in Aiquara, the prenatal care was identified as a protective factor against the development of malocclusions. Programs in the public health system in which parents are guided from the prenatal period by the doctor and referred to a dentist in the child's first months of life help in the prevention of early weaning and in avoiding introduction and maintenance of deleterious habits, capable of acting in a harmful way in the child's muscular and skeletal facial development. Thereby, breastfeeding is strongly encouraged by these governmental programs in order to meet the baby's dietary needs, as well as protection against infections and diseases, in addition to fulfilling their affective needs, also providing the correct breathing pattern and adequate development of the stomatognathic system. Thus, the longer duration of breastfeeding causes the rise of deleterious habits less frequently and, consequently, avoiding malocclusions $[25]$.

The present study also found in PCA that the duration of using a pacifier for more than one year increases the prevalence of malocclusions. This association was also identified in a study carried out with 81 children aged 4 years, in Porto Alegre/RS, Brazil, considering that the duration of pacifier use, in the multivariate analysis, remained associated with anterior open bite and posterior crossbite (Poisson Regression $=1.051)$. Another research conducted in São Paulo, with 113 children using pacifiers, found that 50.4\% of them used for up to 36 months and developed malocclusions [8].

The duration of use of the pacifier interferes with the normal eruption of the incisors, which can cause an anterior open bite [8]. When using a pacifier, the upper anterior teeth experience vestibular and apical strength while the lower incisors are pressed to the lingual, contributing to the increase in overjet [1]. It is also worth noting that the transverse growth of the face may be impaired due to the intensity, frequency and duration of the pacifier sucking habit, as the buccinator muscle becomes overfunctional. The act of sucking the pacifier drives the tongue to be lowered in the oral cavity, which leads to an expansion of the jaw, contributing to maxillary atresia and consequently development of cross bite, that may even display as a bilateral cross bite $[24]$.

In regard to duration of onychophagia, our data of PCA showed an association with malocclusions. In São Paulo/SP, Brazil, when analyzing 107 children aged 3 to 5 years, it was found a prevalence of onychophagia of $32 \%$, and $18.2 \%$ of the children had some type of malocclusion [25]. Another study conducted in Suzano/SP, Brazil, evaluated 266 children aged 4 to 6 years and showed a prevalence of onychophagia of $23.5 \%$ [26]. In these two studies, the nail biting lasted more than a year and preschoolers who presented this habit had a higher prevalence of anterior open bite, posterior cross bite and excessive overjet. Also, in RecifePE, Brazil, 970 children aged 5 to 12 years were evaluated and it was found that $60.8 \%$ of them had deleterious oral habits, with onychophagia being the most prevalent $44.6 \%$. With advancing age, oral habits tend to decrease, with the exception of onychophagia, which tends to increase [27].

Herein, onychophagia is a parafunctional habit that can cause temporomandibular joint dysfunction syndrome, with symptoms such as limitation of mouth opening, joint dislocation and pain during mandibular movements [27]. In addition, the habit of biting nails, can also cause dental fractures, gingival inflammation, root resorption and infections due to the ingestion of huge number of bacteria present under the nail [26].

Although the literature shows that the prevalence of thumb/finger sucking is significantly lower than use of pacifiers [23-25], the damage caused by this deleterious habit to occlusion tends to be more severe and more frequent $[26,27]$. In the present study, thumb/finger suction time was the third component (7\%) of PCA. 
A study that evaluated 388 children aged 3 to 5 years residing in Domingos Martins/ES, Brazil, found that when the habit of digital sucking lasts more than one year, the child is four time more likely to developing an anterior open bite than those who did not have this behavior [9].

The most common malocclusion found in the literature due to the digital sucking habit was the open bite $[9,24,26]$ other changes such as the presence of orofacial myofunctional disorders, oral breathing, tongue thrusting, atresia of the palate and absence of lip sealing are functions of the stomatognathic system, occlusion and maxillary bones and once established, even with the removal of the habit, are hardly spontaneously corrected [24].

The use of a pacifier for more than one and a half year increases the chance of a child having an open anterior bite by 3.2 times. Higher values were identified in Natal/RN, Brazil, where the chance of children using a pacifier to present an anterior open bite was 11.6 times greater [27].

Finally, sucking habits are considered normal up to three years of age, but when they persist, they significantly increase the probability of undesirable development of dental arches and occlusal characteristics [9]. Thus, if the stimulus is removed, before the eruption of the first permanent teeth, satisfactory selfcorrection occurs with normal growth and occlusal balance due to the ease of growth and effectiveness in the tissue remodeling process, but this will depend on genetics and duration of the habit [27].

Small towns, with a rural base and low socioeconomic and demographic indicators face economic, social and political difficulties, which can impact on worse health indicators that tend to be unequal and remain with the worst levels of access to oral health services, mainly in Northeast region of Brazil [11]. In addition, it is clear that small towns have weaknesses in implementing prevention and promotion strategies in oral health leading to early childhood illness [28].

Multiprofessional work and transdisciplinary actions must be carried out to promote, prevent, and recover oral health of children. On the other hand, it is understood that there are factors that go beyond the limits of performance not only of professionals, but also of caregivers.

\section{Conclusion}

The prevalence of malocclusion in children aged 4 to 6 years living in the town of Aiquara-BA is high. Among malocclusions, overjet, overbite and primary canine class II were, respectively, the ones that most affected preschool children. Deleterious oral habits, such as pacifier sucking, onychophagia and thumb/finger sucking, and dental caries are associated with malocclusions. Therefore, the need to create and/or optimize permanent educational activities is emphasized, in order to reduce risk factors to malocclusions.

\section{Authors' Contributions}

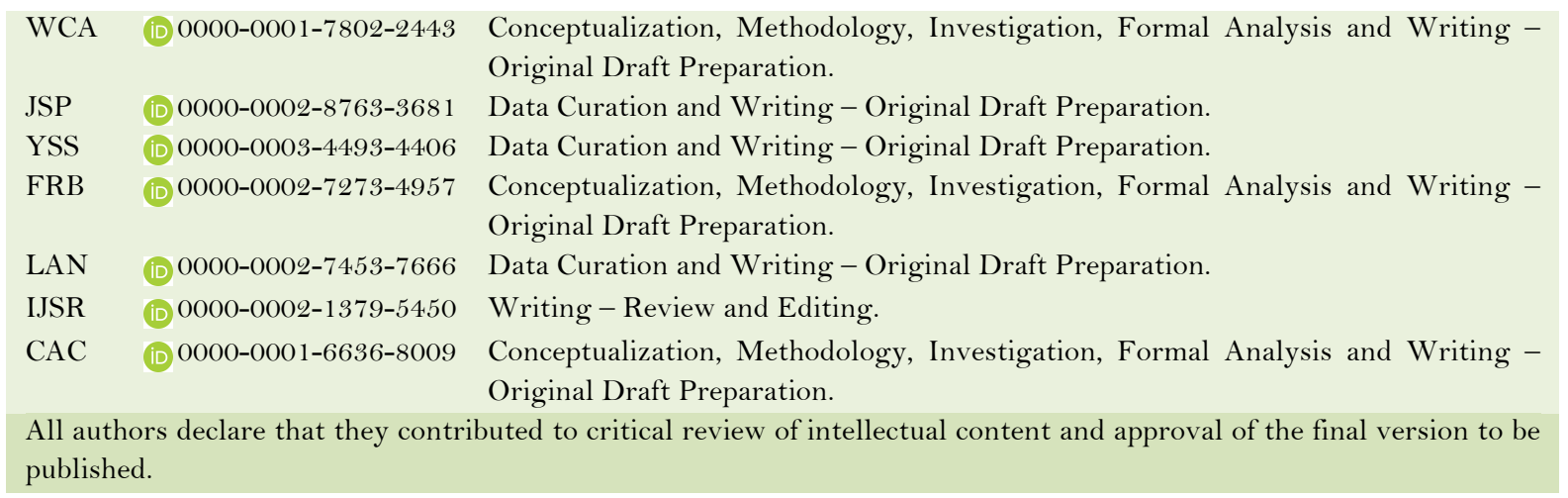




\section{Financial Support}

Bahia State Research Support Foundation (Grant No. BOL0871/2017).

\section{Conflict of Interest}

The authors declare no conflicts of interest.

\section{References}

[1] Pereira JGM, Machado NF, Lima DMD, Sarmento LC, Gomes AMM, Dadalto ECV. Anterior open bite and posterior crossbite in deciduos dentition among preterm and full term children. Ortho Sci Orthod Sci Pract 2018; 10(40):25-31.

[2] Leong PM, Gussy M, Barrow SYL, de Silva-Sanigorski A, Waters E. A systematic review of risk factors during first year of life for early childhood caries. Int J Paediatr Dent 2013; 23(4):235-50.

https://doi.org/10.1111/j.1365-263X.2012.01260.x

[3] Moimaz SAS, Rocha NBD, Garbin AJI, Saliba O. The effect of breastfeeding in the acquisition of non-nutritive sucking habits and malocclusion prevention. Rev Odontol UNESP 2013; 42(1):31-6.

https://doi.org/10.1590/S1807-25772013000100006

[4] Brasil. Ministério da Saúde. Secretaria de Atenção à Saúde. SB Brasil 2010: Pesquisa Nacional de Saúde Bucal: Resultados Principais 2010. Brasília: Ministério da Saúde; 2011. [In Portuguese].

[5] Prabhakar RR, Saravanan R, Karthikeyan MK, Vishnuchandran C, Sudeepthi. Prevalence of malocclusion and need for early orthodontic treatment in children. J Clin Diagn Res 2014; 8(5):ZC60-1. https://doi.org/10.7860/JCDR/2014/8604.4394

[6] Kramer PF, Feldens CA, Ferreira SH, Bervian J, Rodrigues PH, Peres MA. Exploring the impact of oral diseases and disorders on quality of life of preschool children. Community Dent Oral Epidemiol 2013; 41(4):327-35. https://doi.org/10.1111/cdoe.12035

[7] Sousa RV, Pinto-Monteiro AK, Martins CC, Granville-Garcia AF, Paiva SM. Malocclusion and socioeconomic indicators in primary dentition. Braz Oral Res 2014; 28(1):54-60. https://doi.org/10.1590/s1806-83242013005000032

[8] Garbin CAS, Garbin AJI, Martins RJ, Souza NPD, Moimaz SAS. Prevalence of non-nutritive sucking habits in preschoolers and parents' perception of its relationship with malocclusions. Ciênc Saúde Coletiva 2014; 19(2):553-8. https://doi.org/10.1590/1413-81232014192.23212012

[9] Miotto MHMB, Rossi FJ, Barcellos LA, Campos DMKS. Anterior open bite in 3-5 years-old children. Arq Odontol 2016; 52(2):111-6.

[10] Matos GC, Santos JC, Granzotti RBG, Silva K, Baldrighi SEZM, César CPHAR. The prevalence of oral habits in preschoolers. Distúrb Comun 2017; 29(1):68-76. https://doi.org/10.23925/2176-2724.2017v29i1p68-76

[11] Santiago BM, Amaral JHL, Zina LG, Werneck MAF, Padilha WWN. A Universidade e o PMAQ-CEO. In: Nilcema F, Goes PSA, Martelli PJL (Eds). Os Caminhos da Saúde Bucal no Brasil: Um Olhar Quali e Quanti Sobre os Centro de Especialidade Odontológicas (CEO) no Brasil. Recife: Editora UFPE; 2016. p.49-62. [In Portuguese ].

[12] Instituto Brasileiro de Geografia e Estatística. Cidades@. Aiquara. Informações Estatísticas 2010. Available from: https://cidades.ibge.gov.br/brasil/ba/aiquara/panorama. [Accessed on December 13, 2018]. [In Portuguese].

[13] Instituto Brasileiro de Geografia e Estatística. Cidades@. Aiquara. Informações Estatísticas 2018. Available from: https://cidades.ibge.gov.br/brasil/ba/aiquara/bolsafamilia. [Accessed on December 15, 2018]. [In Portuguese].

[14] World Health Organization. Oral Health Surveys: Basic Methods. 4th ed. Geneva: WHO; 1997.

[15] Sousa RV. Prevalência, fatores associados e impacto da má oclusão na qualidade de vida de pré-escolares de campina grande-PB. [Dissertation]. Paraíba: Universidade Estadual da Paraíba, Programa de pós-Graduação em Odontologia; 2013. [In Portuguese].

[16] Hammer Ø, Harper DAT, Ryan PD. PAST: Paleontological statistics software package for education and data analysis. Palaeontol Electronica 2001; 4(1):9.

[17] Hair Junior JF, William B, Babin B, Anderson RE. Análise Multivariada de Dados. 6th ed. Porto Alegre: Bookman. 2009. [In Portuguese].

[18] Yan W, Kang MS. GGE Biplot Analysis: A Graphical Tool for Breeders, Geneticists, and Agronomists. Boca Raton: CRC Press; 2002.

[19] Alves JAO, Forte FDS, Sampaio FC. Prevalence of malocclusions and social-economic conditions of children aged 5 and 12 years old in the Familiar Health Unit of Castelo Branco III, João Pessoa/PB. Rev Dent Press Ortod Ortop Facial 2009; 14(3):52-9. https://doi.org/10.1590/S1415-54192009000300008

[20] Rossi TRA, Lopes LS, Cangussu MCT. Influence of familiar context and malocclusion in children aged 0-5 years-old in the city of Salvador, State of Bahia, Brazil. Rev Bras Saúde Matern Infant 2009; 9(2):139-47. https://doi.org/10.1590/S1519-38292009000200003 
[21] Neu AP, Silva AMTD, Mezzomo CL, Busanello-Stella AR, Moraes ABD. Relationship between time and type of breastfeeding and stomatognathic system functions. Rev CEFAC 2013; 15(2):420-6. https://doi.org/10.1590/S1516-18462012005000020

[22] Arebalo LR, Vedovello SAS, Santamaria Junior M, Kuramae M, Tubel CAM. Relationship between temporomandibular disorders and posterior crossbite. Rev Gaúch Odontol 2010; 58(3):323-6.

[23] Pereira MR, Jardim LE, Figueiredo MC, Faustino-Silva DD. Prevalence of malocclusion in four-year-old children and associated factors in Primary Health Care. Stomatos 2017; 23(45):49-58.

[24] Leôncio LL, Furtado KKFA, Chacon LD, Nóbrega CBC, Costa LED, de Sousa QF. Prevalence of malocclusion among five-year-old children in Patos, PB, Brazil. Arq Odontol 2015; 51(1):25-31.

[25] Lima GN, Cordeiro CDM, Justo JDS, Rodrigues LCB. Anterior open bite and oral habits in children. Rev Soc Bras Fonoaudiol 2010; 15(3):369-75. https://doi.org/10.1590/S1516-80342010000300010

[26] Zapata M, Bachiega JC, Marangoni AF, Jeremias JEM, Ferrari RAM, Bussadori SK, et al. Occurrence of anterior open bite and harmful oral habits in children from 4 to 6-year old. Rev CEFAC 2010; 12(2):267-71. https://doi.org/10.1590/S1516-18462010000200013

[27] de Vasconcelos FMN, Massoni ACDLT, Ferreira AMB, Katz CRT, Rosenblat A. Occurrence of deleterious oral habits in children from Recife, Pernambuco, Brazil. Pesqui Bras Odontopediatria Clín Integr 2009; 9(3):327-32. https://doi.org/10.4034/1519.0501.2009.0093.0013

[28] Casotti CA, Franscisco KMS, Nery AA, Sacramento MS. Correlação entre os índices de higiene oral simplificada e cárie dentária. Odontol Clín-Cient 2014; 13(1):345-9. [In Portuguese]. 